\title{
Patrycja Szcześniak
}

Uniwersytet im. Adama Mickiewicza w Poznaniu

\section{Struktura i determinanty bezrobocia $w$ krajach rozwijajacych się}

\section{WPROWADZENIE}

$\mathrm{P}$ RACA, JAKO PODSTAWOWA I ŚWIADOMA DZIAŁALNOŚć CZŁOWIEKA, w XXI w. staje się w coraz większym stopniu uprawnieniem deficytowym. Jej brak negatywnie wpływa na cały system społeczno-gospodarczy wszystkich państw świata niezależnie od ich położenia geograficznego. Skutki nierównego podziału pracy, które powodują kryzys zatrudnienia i masowe bezrobocie będące trwałym zjawiskiem strukturalnym, widoczne są szczególnie w krajach tzw. Trzeciego Świata. Celem niniejszego artykułu jest próba uzyskania odpowiedzi na pytanie: Dlaczego państwom tym tak trudno jest wprowadzać skuteczną politykę rynku pracy, która doprowadziłaby „do zmiany struktury produkcji i zatrudnienia, a także popytu na pracę i charakteru pracy"1 ?

Wykonywanie pracy stanowi podstawę przekształcania istniejących systemów społeczno-gospodarczych, poprzez przyczynianie się do „ciągłego rozwoju nauki i techniki, a zwłaszcza do nieustannego podnoszenia poziomu kulturalnego i moralnego społeczeństwa, w którym żyje (...) człowiek" ${ }^{2}$. Natomiast dokonujące się przemiany w zakresie technologii, ekonomii i polityki wywierają na świat pracy i produkcji wpływ, który porównać można do rewolucji przemysłowej w XIX w. Postęp technologiczny, prowadzenie przez państwa polityki neoliberalnej, jak i niektóre procesy globalizacyjne, w znacznym stopniu powodują rewizje struktur ekonomicznych i podziału pracy, co nieuchronnie prowadzi do bezrobocia. Z kolei „niemożność podjęcia pracy jest źródłem frustracji, degraduje człowieka, obniża jego samoocenę, zuboża ludzi psychicznie i materialnie. Jest wyrazem niedorozwoju moralnego i gospodarczego społeczeństw”3.

${ }^{1}$ M. Szylko-Skoczny, Problemy spoteczne $w$ sferze pracy, [w:] Polityka spoteczna, red. G. Firlit-Fesnak, M. Szylko-Skoczny, Warszawa 2011, s. 218.

${ }^{2}$ Por. Jan Paweł II, Encyklika o pracy ludzkiej „Laborem exercens” z okazji 90. rocznicy „Rerum novarum”, Watykan 1981.

3 T. Borutka, Społeczne Nauczanie Kościoła. Teoria i zastosowanie, Kraków 2008, 
Aby wyjaśnić powyższe zjawiska w kontekście sytuacji państw tzw. Trzeciego Świata, należy w pierwszej kolejności dokonać rewizji podstawowych pojęć.

\section{BEZRobocie}

SFORMUŁOWANIE UNIWERSALNEJ I PRECYZYJNEJ DEFINICJI BEZROBOCIA, która oparta będzie na jednoznacznych i obiektywnych kryteriach jest zadaniem skomplikowanym, gdyż zjawisko to posiada złożony i wieloaspektowy charakter. Sprawia to, że inne kryteria wyznaczające treść definicji bezrobocia interesują politologa, ekonomistę czy socjologa, a jeszcze inne demografa czy prawnika.

Krystyna Mlonek stwierdza, że „w skali makroekonomicznej i makrospołecznej najczęściej stosowanym wyznacznikiem pojęcia « ‘bezrobocia » jest tzw. przedmiotowe i podmiotowe podejście do problemu" 4 . W rozumieniu przedmiotowym bezrobocie jest kategorią analityczną rynku pracy, co oznacza niepełne wykorzystywanie jednego z czynników wytwórczych (niezrealizowaną podaż siły roboczej), innymi słowy stan nierównowagi między podażową a popytową stroną zatrudnienia, czyli brak równowagi między zasobami pracy a miejscami pracy. Definicja ta ujmuje pracę ,jako parametr rynku pracy i skupia uwagę na zmiennych wyrażonych liczbowo, wzajemnych proporcjach popytu i podaży «siły roboczej〉»"5. W rozumieniu podmiotowym bezrobocie rozpatrywane jest z perspektywy osób dotkniętych brakiem pracy. To ujęcie problemu odsłania takie aspekty zjawiska, jak „społeczne i demograficzne cechy zbiorowości bezrobocia, konsekwencje bezrobocia dla osobowości osób nim dotkniętych, dla rodziny, społeczności lokalnych (regionów), w których bezrobocie jest bardzo duże"6.

\section{Kraje TrZeciego ŚWIATA CZY KRAJE ROZWIJAJĄCE SIE ?}

UŻYWANY OD POCZĄTKU NINIEJSZEGO ARTYKUŁU termin kraje tzw. Trzeciego Świata, powszechnie swego czasu stosowany, dziś nie jest już tak często spotykany. Wiadomą rzeczą jest, iż pojęcie to wywodzi się z czasów zimnej wojny, a więc z okresu od 1946 r. do 1991 r., kiedy świat podzielony był na kraje bloku kapitalistycznego i socjalistycznego. Te pierwsze

S. 253 .

${ }^{4}$ K. Mlonek, Tradycje badań bezrobocia $w$ Polsce - zagadnienie metodologiczne, [w:] Socjologia bezrobocia, red. T. Borkowski, A. Marcinkowski, Katowice 1999, s. 62.

${ }_{5}$ T. Borkowski, A. Marcinkowski, Bezrobocie $w$ perspektywie socjologicznej, [w:] Socjologia bezrobocia, red. T. Borkowski, A. Marcinkowski, Katowice 1999, s. 17.

${ }^{6}$ Ibidem, s. 18. 
określane były mianem Pierwszego Świata, kraje socjalistyczne natomiast (dziś nazywane raczej krajami bloku sowieckiego lub podobnie) - mianem Drugiego Świata. Jak można zauważyć określenia te mają charakter wartościujący, a we współczesnych stosunkach międzynarodowych raczej unika się tego typu sformułowań, zwłaszcza gdy mają charakter negatywny. Trzeci Świat to niewątpliwie określenie gorszej części świata. Obecnie zdecydowanie chętniej używa się pojęć, które wywołują pozytywne skojarzenia, co może być związane z poprawnością polityczną. Takim pojęciem jest stwierdzenie kraje rozwijające się, które posiada zabarwienie pozytywne. Dlatego też określenie krajów Trzeciego Świata jest rzadkością i coraz częściej mówi się o krajach rozwijających się7.

Przyznać jednak należy, iż termin Trzeci Świat jest jednym z najważniejszych pojęć, które pojawiły się w XX w. Jego globalna wręcz popularność z jednej strony stała się nieodłącznym elementem poważnej dyskusji o kształcie świata, z drugiej zaś kształtowała ludzkie wyobrażenia o świecie. Termin ten oddziaływał nie tylko na myślenie o rzeczywistości, lecz także na jej kształtowanie. I właśnie z uwagi na to i na potrzeby niniejszego artykułu, pojęcie Trzeciego Świata, jak i krajów rozwijających się stosowane będą zamiennie.

BEZROBOCIE W KRAJACH ROZWIJAJĄCYCH SIĘ - JEGO STRUKTURA I DETERMINANTY ZJAWISKO BEZROBOCIA JEST KWESTIA NIEZWYKLE ISTOTNĄ i bardzo aktualną, zarówno w krajach rozwiniętych, jak i w krajach rozwijających się. Można byłoby pokusić się o porównanie tego zjawiska, ale bezrobocie w krajach rozwiniętych nie jest jakościowo identyczne, ani istotowo tożsame z bezrobociem w krajach Trzeciego Świata. Andrzej Szafulski postuluje, że „ze względu na odmienność warunków ekonomicznych nie można struktur przejętych z Zachodu, przystosowywać i przenosić na grunt krajów nierozwiniętych. Zjawisko bezrobocia posiada bowiem odmienną istotę na dwóch różnych obszarach ekonomiczno-społecznych. Jest zatem porównywalne raczej w kategoriach jakościowych, a nie ilościowych. Ważne jest przy tym, że w krajach zachodnich bezrobotny otrzymuje zasiłek i nie staje w obliczu śmierci głodowej czy biologicznego wyniszczenia, jak ma to miejsce w krajach nierozwiniętych"s.

${ }^{7}$ J. Grzenia, Kraje Trzeciego Świata, http://poradnia.pwn.pl/lista.php?szukaj=trz eci+\%B6wiat\&kat=18, 24.03.2011 r.

${ }^{8}$ A. Szafulski, Nierówności $w$ świecie $w$ świetle podstawowych zasad społecznych, Wrocław 1999, s. 56. 
Tabela 1. Najwyższe wskaźniki bezrobocia w latach 1998-2002

\begin{tabular}{|c|c|c|}
\hline Lp. & Państwo & Proc. siły roboczej \\
\hline 1. & NAMIBIA & 33,8 \\
\hline 2. & MACEDONIA & 31,9 \\
\hline 3. & ZACHODNI BRZEG I GAZA & 31,3 \\
\hline 4. & RPA & 29,5 \\
\hline 5. & ALGIERIA & 27,3 \\
\hline 6. & POLSKA & 19,9 \\
\hline 7. & SŁOWACJA & 18,5 \\
\hline 8. & ARGENTYNA & 17,8 \\
\hline 9. & BUŁGARIA & 17,6 \\
\hline 10. & URUGWAJ & 17,2 \\
\hline 11. & ALBANIA & 15,8 \\
\hline 12. & BOTSWANA & 15,8 \\
\hline 13. & WENEZUELA & 15,8 \\
\hline 14. & KOLUMBIA & 15,7 \\
\hline 15. & JAMAJKA & 15,7 \\
\hline 16. & DOMINIKANA & 15,6 \\
\hline 17. & CHORWACJA & 14,8 \\
\hline 18. & BURUNDI & 14,0 \\
\hline 19. & ANTYLE HOLENDERSKIE & 14,0 \\
\hline 20. & SURINAM & 14,0 \\
\hline 21. & LITWA & 13,8 \\
\hline 22. & SERBIA I CZARNOGÓRA & 13,8 \\
\hline 23. & JORDANIA & 13,2 \\
\hline 24. & PANAMA & 13,2 \\
\hline 25. & GRUZJA & 12,3 \\
\hline 26. & IRAN & 12,3 \\
\hline 27. & PORTORYKO & 12,3 \\
\hline 28. & NIKARAGUA & 12,2 \\
\hline 29. & ŁOTWA & 12,0 \\
\hline 30. & SYRIA & 11,7 \\
\hline 31. & MAROKO & 11,6 \\
\hline 32. & JEMEN & 11,5 \\
\hline 33. & HISZPANIA & 11,4 \\
\hline 34. & TRYNIDAD I TOBAGO & 10,8 \\
\hline 35. & TURCJA & 10,6 \\
\hline 36. & BARBADOS & 10,3 \\
\hline 37. & ESTONIA & 10,3 \\
\hline 38. & IZRAEL & 10,3 \\
\hline 39. & UKRAINA & 10,2 \\
\hline 40. & FILIPINY & 9,8 \\
\hline
\end{tabular}

Źródło: The Economist, Pocket. Świat w liczbach 2005, Warszawa 2005, s. 57. 
Brak sprawnej służby statystycznej w większości krajów rozwijających się uniemożliwia udokumentowanie faktycznego stanu bezrobocia. Międzynarodowa Organizacja Pracy podała, że pomimo, iż poziom bezrobocia na świecie rośnie od czasu wybuchu kryzysu w 2007 r., to bezrobotnych w krajach rozwijających się ubyło (najwięcej spadło w Brazylii, Kazachstanie, Sri Lance, Tajlandii i Urugwaju).

Najwyższa średnia stopa bezrobocia w 2010 r. jest w Afryce i wynosi 23,6\% (w roku 1975 średnia stopa bezrobocia w Afryce wynosiła $45 \%$, a zatem zmniejszyła się o 21,4\%). W tabeli 1 przedstawione zostały dane dotyczące najwyższych wskaźników bezrobocia na świecie.

Ubóstwo jest jednym z podstawowych problemów krajów rozwijających się, a wydobycie się z niego stanowi główny cel gospodarczy i polityczny. „W porównaniu z gospodarkami uprzemysłowionymi większość państw rozwijających się jest uboga w czynniki produkcji niezbędne do nowoczesnej produkcji: kapitał i wykwalifikowaną siłę roboczą"9. Wszystko to wraz z niestabilnością gospodarczą, zagrożeniem prawa własności i niewłaściwą polityką gospodarczą jest główną przyczyną i tak ciągle wysokiego poziomu bezrobocia. To wręcz błędne koło, które przerwać może jedynie pomoc krajów rozwiniętych.

Paul Krugman oraz Maurice Obstfeld podają podział gospodarek świata na cztery główne kategorie:

1) gospodarki o niskim dochodzie (Indie, Pakistan z większością sąsiadów oraz znaczna część subsaharyjskiej Afryki);

2) gospodarki o dochodzie powyżej średniego (Chiny, większość państw Bliskiego Wschodu, wiele krajów Ameryki Łacińskiej i Środkowej, wiele krajów byłego Związku Socjalistycznych Republik Radzieckich oraz większość pozostałych krajów afrykańskich);

3) gospodarki o dochodzie poniżej średniego (pozostałe kraje Ameryki Łacińskiej, Arabia Saudyjska, Malezja, Afryka Południowa, Polska, Węgry, Czechy i Słowacja);

4) gospodarki o wysokim dochodzie (bogate uprzemysłowione gospodarki rynkowe oraz część wyjątkowo pomyślnie rozwijających się takich państw jak Izrael, Kuwejt, Korea Południowa i Singapur) ${ }^{10}$.

Pierwsze trzy kategorie stanowią katalog państw, które są względnie zacofane w rozwoju w stosunku do gospodarek państw rozwiniętych.

9 P. R. Krugman, M. Obstfeld, Ekonomia międzynarodowa. Teoria i praktyka. T. 2, Warszawa 2008, s. 467.

${ }^{10}$ Ibidem. 
Ryszard Piasecki proponuje trochę inny podział postulując, że kraje rozwijające się są ogromnie zróżnicowane pod względem stopnia rozwoju cywilizacyjnego i wysokości Produktu Krajowego Brutto na 1 mieszkańca. Autor dzieli państwa Trzeciego Świata na dwie grupy:

1) kraje o niskim PKB na 1 mieszkańca (410 USD), do których zalicza się:

1. w Afryce m.in. Angolę, Demokratyczną Republikę Konga, Mozambik, Niger, Liberię, Sudan, Tanzanię, Togo;

2. w Azji m.in. Afganistan, Bangladesz, Mongolię, Pakistan, Wietnam;

3. w Ameryce Łacińskiej np. Haiti;

2) kraje o średnim dochodzie:

1. podgrupa krajów średnich o niższym dochodzie (1 200 USD):
a. w Afryce Namibia;
b. w Azji m.in. Chiny, Filipiny, Sri Lanka, Tajlandia;
c. w Ameryce Łacińskiej m.in. Boliwia, Gwatemala, Ko- lumbia, Kuba, Paragwaj;

2. podgrupa krajów średnich o wyższym dochodzie (4900 USD):

a. w Afryce m.in. Botswana, Gabon, RPA;

b. w Azji m.in. Arabia Saudyjska, Liban;

c. w Ameryce Łacińskiej m.in. Argentyna, Brazylia, Wenezuela $^{11}$.

Do krajów rozwijających się zalicza się także kilka krajów o bardzo wysokim PKB na 1 mieszkańca, np. Kuwejt, Zjednoczone Emiraty Arabskie, gdyż charakteryzują się one głębokim dualizmem społeczno-ekonomicznym, technologicznym i regionalnym.

Już sam fakt istnienia podziałów wśród państw rozwijających się sugeruje, że pod terminem tym kryje się znaczące zróżnicowanie, które wpływa na strukturę i determinanty bezrobocia w tych państwach. Niemożliwe jest, aby w niniejszym opracowaniu rozważać przyczyny i skutki bezrobocia z uwzględnieniem sytuacji geograficznej i historycznej każdego państwa zaliczanego do Trzeciego Świata. Można jednak wyodrębnić pewne wspólne elementy:

- niski przeciętny standard cywilizacyjny;

- niski poziom PKB na 1 mieszkańca;

${ }^{11}$ R. Piasecki, Kraje rozwijające się, http://biznes.pwn.pl/haslo/3926914/krajerozwijajace-sie.html, 24.03.2011 r. 
- przewaga zatrudnionych w rolnictwie (z reguły prymitywnym);

- dualizm (nawet pluralizm) ekonomiczno-społeczny, technologiczny i regionalny;

- niski poziom oświaty, nauki i opieki zdrowotnej;

- wysoki przyrost naturalny;

- chroniczne wysokie bezrobocie o charakterze strukturalnym i sezonowym ${ }^{12}$.

Wszystkie powyższe elementy występują jedynie w krajach najbiedniejszych Trzeciego Świata, czyli w większości państw afrykańskich. Aby zakwalifikować dane państwo do krajów rozwijających się wystarczą 2 lub 3 cechy z powyższych. Elementy te można jednak wartościować. Za najważniejszą cechę niedorozwoju jest uznawany „dualizm ekonomiczno-społeczny, technologiczny i regionalny (zderzenie różnych poziomów cywilizacyjnych: ogromne nierówności dochodowe, kontrasty społeczne, zderzenie sektora nowoczesnego z tradycyjnym)"13.

Analizując cechy zacofania państw rozwijających się można analogicznie wyodrębnić determinanty bezrobocia w tych państwach, które są ogólnymi i pogrupowanymi problemami odnoszącymi się do większości krajów Trzeciego Świata. Są to:

- kontekst historyczny, archaiczne struktury społeczne i brak stabilności politycznej;

- wysoki przyrost naturalny i warunki socjalne;

- struktura gospodarki i inwestycje.

KONTEKST HISTORYCZNY, ARCHAICZNE STRUKTURY SPOŁECZNE I BRAK STABILNOŚCI POLITYCZNEJ

Państwa Trzeciego Świata, poza kilkoma wyJątKami, są dawnymi koloniami. Wśród nich państwa położone w Ameryce Łacińskiej uzyskały niepodległość na początku XIX w., a niemal wszystkie pozostałe dopiero po drugiej wojnie światowej, głównie w latach 60. XX w., a więc w czasach zimnej wojny. Między innymi właśnie to wpłynęło na fakt, iż państwa te stały się obiektem zainteresowania zarówno państw zachodnich, które nie chciały tracić swoich wpływów, jak i Związku Radzieckiego, który napędzany chęcią utworzenia socjalistycznego supermocarstwa starał się rozszerzyć swoją strefę wpływów również na państwa Trzeciego Świata. Spowodowało to jeszcze większy podział wśród państw rozwijających się, które i tak były już mocno podzielone.

\footnotetext{
${ }^{12}$ Ibidem.

${ }^{13}$ Ibidem.
} 
Ponieważ państwa te są stosunkowo młode w rzeczywistości dopiero poszukują swojej tożsamości. Ich czas na niepodległość przypadł w okresie zimnej wojny, co miało znaczny wpływ na ich obecny kształt. Część z nich upatruje swoją przyszłość w demokracji i kapitalizmie, część znacjonalizowała prywatną własność, ziemie czy przemysł, a jeszcze inne państwa próbują odnaleźć się gdzieś po środku.

Sam przebieg procesu kolonizacji Afryki, Ameryki Południowej oraz Azji również nie pozostał bez echa, szczególnie w przypadku Afryki. Pamiętać należy, że „celem istnienia kolonii w trzecim świecie było zapewnienie bogactwa potęgom kolonialnym - nie na odwrót"14. Oznacza to, że przez bardzo długi czas tereny te były w nadmierny sposób eksploatowane.

Równie istotne jest to, że kolonizatorzy tworzyli swoje imperia kreśląc na mapie politycznej kontynentu ich kształty za pomocą linijki i ołówka, nie zważając na ludność pierwotnie tam zamieszkującą. Spowodowało to, że w obecnych państwach żyją od wieków wrogie sobie plemiona, a te które współżyły w zgodzie i współpracy zostały rozdzielone. Za późno już, by dokonywać zmian na mapie politycznej świata, ale ludność pierwotna domaga się swoich praw i niepodległości, co powodować będzie coraz więcej konfliktów etnicznych i brak stabilności politycznej. Uniemożliwia to skupienie się władz państwowych na rozwoju gospodarczym, które zamiast rozbudowywać infrastrukturę, rozwijać współpracę międzynarodową i ściągać zagranicznych inwestorów muszą inwestować nie tyle $\mathrm{w}$ walkę $\mathrm{z}$ nierównościami etnicznymi, bo na to ich po prostu nie stać, ale w łagodzenie skutków tych konfliktów. Kolonializm niósł ze sobą również problem niewolnictwa i apartheidu, a wyraźnie należałoby podkreślić fakt, że „każdy system podziału społecznego, szczególnie tak silny ja niewolnictwo i apartheid, odciska w społeczeństwie ślady, które trudno wymazać. Beneficjentom podziału, niezależnie od ich przywiązania do ideałów egalitaryzmu, nie jest łatwo wyrzec się korzyści. Ofiary odczuwają krzywdę i przekazują kolejnym pokoleniom obciążenia związane z ich niekorzystną sytuacją"15.

Zarówno konflikty etniczne, jak i próba uzyskania wpływu przez dwa bloki o największym potencjale ekonomicznym i militarnym spowodowało, że przez dłuższy czas w większości krajów rozwijających

${ }^{14}$ L. C. Thurow, Przyszłość kapitalizmu. Jak dzisiejsze sity ekonomiczne ksztattuja świat jutra, Wrocław 1999, s. 161.

${ }_{15}$ M. Hill, Polityka społeczna we współczesnym świecie. Analiza porównawcza, Warszawa 2012 , s. 264. 
się rządziły reżimy wojskowe, a skutkami dłuższego panowania takich rządów są najczęściej „spory pomiędzy różnymi rodzajami ugrupowań wojskowych, mała kompetencja w sprawach gospodarczych i dalszy podział społeczeństwa powodowany wyłączeniem wolnej prasy i prawa do krytycznych wystąpień. (...) W Trzecim Świecie istnieją nadal dyktatury wojskowych, ale zawsze znajdują one uznanie wśród ludności cywilnej"16. Ich działania jednak nigdy nie spowodują przyspieszenia wzrostu gospodarczego, mogą jedynie skutkować pogłębiającą się zapaścią gospodarczą. Taka sytuacja zdecydowanie nie wpływa pozytywnie na tworzenie nowych miejsc pracy, które stanowią jedyną alternatywę dla bezrobocia.

\section{WYSOKI PRZYROST NATURALNY I WARUNKI SOCJALNE}

W PAŃSTWACH AFRYKI ODNOTOWUJE SIĘ utrzymującą się od kilkudziesięciu lat wysoką liczbę urodzeń, która przybrała rozmiary „eksplozji demograficznej”. Wpłynęło na ten fakt wiele czynników m.in. proces dekolonizacji (nastąpił koniec niewolnictwa i mimo wszystko poprawiły się warunki życiowe), znaczna przewaga ludzi młodych w strukturze wieku oraz tradycja rodzin wielodzietnych. Przyrost naturalny w państwach na świecie przedstawia rysunek 1.

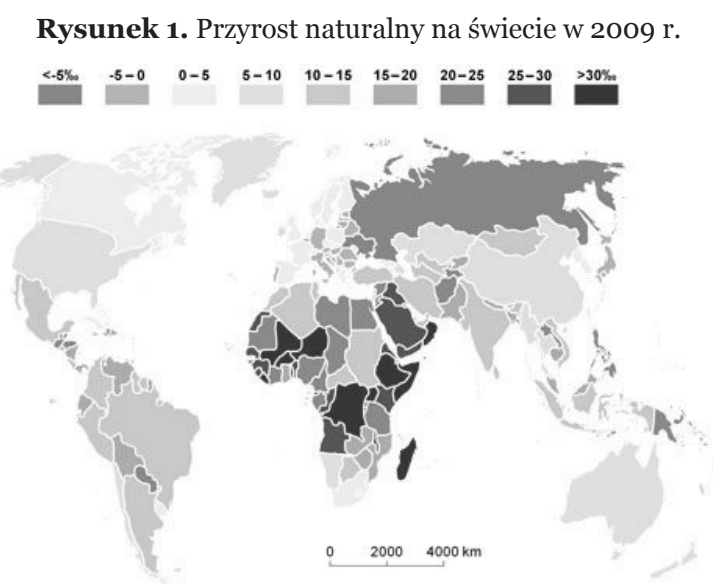

Źródło: Przyrost naturalny, migracje, przyrost rzeczywisty na świecie, http://www. wiking.edu.pl/article.php?id=267, 25.03.2011 r.

${ }^{16}$ A. Szafulski, Nierówności w świecie..., op. cit., s. 49. 
Tabela 2. Populacje o najszybszym przyroście.

\begin{tabular}{|c|c|c|c|c|c|}
\hline \multicolumn{3}{|c|}{ 1980-1985 } & \multicolumn{3}{|c|}{ 2020-2025 } \\
\hline Lp. & PAŃSTWO & $\begin{array}{c}\text { ŚREDNI } \\
\text { ROCZNY } \\
\text { WZROST, \% }\end{array}$ & Lp. & PAŃSTWO & $\begin{array}{c}\text { ŚREDNI } \\
\text { ROCZNY } \\
\text { WZROST, \% }\end{array}$ \\
\hline 1. & KATAR & 9,06 & 1. & NIGER & 3,37 \\
\hline 2. & $\begin{array}{c}\text { ZJEDN. } \\
\text { EMIRATY } \\
\text { ARAB. }\end{array}$ & 8,49 & 2. & JEMEN & 3,35 \\
\hline 3. & GWINEA PED. & 7,15 & 3. & UGANDA & 3,26 \\
\hline 4. & $\begin{array}{l}\text { ARABIA } \\
\text { SAUD. }\end{array}$ & 5,92 & 4. & SOMALIA & 3,14 \\
\hline 5. & ANDORA & 5,36 & 5. & MALI & 2,97 \\
\hline 6. & OMAN & 5,04 & 6. & BURKINA FASO & 2,73 \\
\hline 7. & KUWEJT & 4,48 & 7. & $\begin{array}{l}\text { GWINEA } \\
\text { BISSAU }\end{array}$ & 2,73 \\
\hline 8. & LIBIA & 4,37 & 8. & ANGOLA & 2,65 \\
\hline 9. & $\begin{array}{c}\text { WYBRZ. } \\
\text { KOŚCI } \\
\text { SŁONIOWEJ }\end{array}$ & 4,32 & 9. & $\begin{array}{c}\text { ZACH. BRZEG } \\
\text { I GAZA }\end{array}$ & 2,59 \\
\hline 10. & KAJMANY & 4,18 & 10. & CZAD & 2,54 \\
\hline 11. & IRAN & 4,16 & 11. & LIBERIA & 2,50 \\
\hline 12. & KAMBODŻA & 4,10 & 12. & KONGO & 2,49 \\
\hline 13. & JORDANIA & 3,92 & 13. & $\begin{array}{c}\text { DEM. REP. } \\
\text { KONGA }\end{array}$ & 2,46 \\
\hline 14. & MAKAU & 3,89 & 14. & AFGANISTAN & 2,30 \\
\hline 15 . & ZIMBABWE & 3,88 & 15. & MADAGASKAR & 2,22 \\
\hline 16. & $\begin{array}{c}\text { ZACH. BRZEG } \\
\text { I GAZA }\end{array}$ & 3,78 & 16. & BURUNDI & 2,15 \\
\hline 17. & KENIA & 3,77 & 17. & MAURETANIA & 2,12 \\
\hline 18. & JEMEN & 3,77 & 18. & ETIOPIA & 2,03 \\
\hline 19. & SYRIA & 3,68 & 19. & KAJMANY & 1,96 \\
\hline 20. & GHANA & 3,59 & 20. & ERYTREA & 1,96 \\
\hline
\end{tabular}

Źródło: Opracowanie własne na podstawie: The Economist, Pocket. Świat..., op. cit., s. 17 . 
Prognozy pokazują, że kraje rozwijające się jeszcze przez długi czas przodować będą na listach populacji o najszybszym przyroście. Biorąc pod uwagę trudności w tworzeniu nowych miejsc pracy, jak i archaiczną strukturę społeczeństwa, wnioskować można, że jeśli wzrost gospodarczy nie będzie odpowiednio szybki i na właściwym poziomie to bezrobocie będzie rosnąc w zastraszającym tempie. Sytuację przyrostu naturalnego w dwóch przedziałach czasowych obrazuje tabela 2.

Zbyt wysoki i za szybki przyrost naturalny powodujący brak odpowiedniej ilości miejsc pracy negatywnie wpływa na warunki socjalne. Niestety stan socjalny państw rozwijających się nie poprawia się. W krajach tych od bardzo długiego czasu odnotowuje się brak odpowiedniej ilości środków żywnościowych i wody pitnej, co powoduje poważne problemy zdrowotne, a przy bardzo niskim poziomie jakości służby zdrowia w krajach Trzeciego Świata, pośrednio wpływa to na wzrost bezrobocia. W związku z tym państwa rozwijające się stanowią obszar szczególnej troski ze strony Organizacji Narodów Zjednoczonych, „której celem jest wyrównywanie różnic i tworzenie szans na lepsze życie grupom ekonomicznie najsłabszym”, co dotyczy również zwalczania skutków bezrobocia ${ }^{17}$.

Warto również zaznaczyć, że głód występujący w tych państwach nie jest sytuacją losową. Jest on stwarzany i podtrzymywany, gdyż świat posiada wystarczającą ilość żywności, by zaspokoić potrzeby każdego człowieka. Głód nie jest następstwem braku żywności, ale następstwem nierównego podziału pomiędzy państwami. A. Szafulski przytacza dane Organizacji Narodów Zjednoczonych do Spraw Wyżywienia i Rolnictwa (FAO), które ukazują, że „w połowie lat siedemdziesiątych w Trzecim Świecie było 435 milionów ludzi niedożywionych. Z tego 304 miliony w Azji, 72 miliony w Afryce, 41 milionów w Ameryce Łacińskiej i 19 milionów na Bliskim Wschodzie. Dane z lat osiemdziesiątych natomiast szacują liczbę ludzi niedożywionych na blisko 500 milionów. Bardziej pesymistyczne dane mówią i o 1 miliardzie" (w październiku 2008 r. FAO podało informację, że liczba ludności niedożywionej wynosi 923 miliony $)^{18}$.

Kolejną istotną kwestią społeczną mającą wpływ na poziom bezrobocia jest system oświaty. Niski poziom kształcenia w krajach rozwijających się powoduje wzrost analfabetyzmu. Nieskuteczny, wręcz niewydolny system oświaty spowodowany jest problemami finansowymi

\footnotetext{
${ }^{17} \mathrm{~J}$. Auleytner, Polityka społeczna $w$ Polsce i na świecie, Warszawa 2011, s. 145.

${ }^{18}$ A. Szafulski, Nierówności w świecie..., op. cit., s. 29.
} 
państw Trzeciego Świata, które odcinają dotacje i pomoc dla szkół i nauczycieli, a środki te przeznaczają przede wszystkim na zbrojenia i wojsko. Wyraźnie należy podkreślić, że analfabeta nie jest w stanie w pełni świadomości korzystać z praw obywatelskich, a przez to uczestniczyć w życiu społecznym i gospodarczym państwa.

Szacuje się, że większość wśród analfabetów stanowią kobiety, co spowodowane jest występowaniem w większości państw rozwijających się tradycyjnego modelu rodziny, w którym od kobiety od najmłodszych lat oczekuje się prowadzenia gospodarstwa domowego, co uniemożliwia im regularne uczęszczanie do szkoły. W niektórych państwach uważa sie, że nauka jest kobietom zbędna albo też, że jest sprzeczna z tradycyjnym wizerunkiem roli kobiety. Czynniki kulturowe i społeczne mają tutaj ogromne znaczenie, ale to ubóstwo stanowi ostateczną barierę na drodze do edukacji. „Według statystyk UNESCO ponad 135 milionów dzieci nie chodzi w ogóle do szkół, wśród nich zaś ponad 60\% stanowią dziewczęta. W wielu krajach Trzeciego Świata ludność żyje głównie na wsi, gdzie brak jest dostępu do szkół. W miastach wcale nie jest lepiej, gdyż migracja ludności ze wsi prowadzi do przepełniania placówek edukacyjnych i tym samym do obniżania jakości kształcenia"19.

Brak wykształcenia uniemożliwia młodym ludziom podjęcie zatrudnienia i podniesienie jakości życia. Również z tego powodu nie tworzą się nowe miejsca pracy, których odpowiednia ilość współdziałałaby z nadmiernym przyrostem naturalnym. Jednak brak odpowiednio wykształconych pracowników skutkuje brakiem opłacalności rozwijania inwestycji zagranicznych $\mathrm{w}$ państwach rozwijających się. Tego typu zależności przedstawić można jako stale powtarzający i warunkujący się cykl.

\section{STRUKTURA GOSPODARKI I INWESTYCJE}

JAK JUŻ ZAUWAŻONO WCZEŚNIEJ KRAJE ROZWIJAJĄCE SIĘ Są grupą bardzo zróżnicowaną, również w kwestii ich podejścia do polityki handlowej, makroekonomicznej i innego typu interwencji państwa w gospodarkę. Państwa te były do siebie znacznie bardziej podobne na początku lat sześćdziesiątych ubiegłego wieku, jednak potem zaczęły następować zmiany. „Kraje wschodnioazjatyckie zaniechały uprzemysłowienia antyimportowego, natomiast przyjęły strategię rozwoju nastawionego

${ }^{19}$ Analfabetyzm na świecie, http://www.wos.org.pl/swiat/analfabetyzm-na-swiecie.html, 25.03.2011 r. 
na eksport. Strategia ta okazała się bardzo skuteczna. Później kraje Ameryki Łacińskiej ograniczyły również bariery handlowe, starając się jednocześnie ograniczyć rolę rządu w gospodarce, by zmniejszyć chronicznie wysoką inflację oraz, w wielu przypadkach, aby stworzyć możliwości dokonywania prywatnych transakcji na rachunkach kapitałowych. Te próby reform przyniosły mieszane rezultaty" ${ }^{20}$.

Kraje rozwijające się, zachęcone sukcesami gospodarek krajów rozwiniętych próbowały przeprowadzać reformy, które mogłyby zbliżyć gospodarki tych krajów do gospodarek krajów uprzemysłowionych. Jednak proces restrukturyzacji całej gospodarki, która musi iść w parze z przeobrażeniami społeczno-kulturowymi to proces długotrwały i nie został jeszcze zakończony. Dlatego o większości krajów Trzeciego Świata, pomimo podjętych działań reformatorskich nie można mówić, że „awansowały”.

Pod względem gospodarczym kraje rozwijające się charakteryzują następujące cechy:

- biorąc pod uwagę opisany wcześniej kontekst historyczny państw rozwijających się nie trudno się domyślić, że gospodarki tych krajów charakteryzuje rozległa i bezpośrednia kontrola gospodarki przez państwo (ograniczenia handlu międzynarodowego, państwowa własność lub kontrola dużych firm przemysłowych, państwowa kontrola wewnętrznych transakcji finansowych, wysoki poziom konsumpcji rządowe, etc.);

- słabe instytucje kredytowe występujące tam gdzie krajowe rynki finansowe zostały zliberalizowane; prowadzi to do sytuacje, że rządowe zabezpieczenia finansowe w postaci na przykład nadzoru bankowego są nieskuteczne z uwagi na brak kompetencji, doświadczenia, jak i istnienie korupcji; to z kolei prowadzi do przeznaczania przez banki pożyczonych funduszy od dysponentów na bardzo ryzykowne projekty; rynki finansowe krajów rozwijających się są szczególnie podatne na kryzysy, gdyż nie potrafią kierować oszczędności do najbardziej efektywnych zastosowań inwestycyjnych;

- gospodarki krajów rozwijających się w znacznej mierze nadal opierają się na rolnictwie i zasobach naturalnych, co stanowi bardzo istotną część eksportu tych krajów; konsekwencją takiego postępowania jest uzależnienie stanu całej gospodarki od danego zasobu naturalnego czy też nieprzetworzonego artykułu rolniczego, np. ropa, kawa, etc.;

${ }^{20}$ P. R. Krugman, M. Obstfeld, Ekonomia międzynarodowa..., op. cit., s. 471. 
Tabela 3. Najszybszy wzrost gospodarczy na świecie

\begin{tabular}{|c|c|c|c|c|c|}
\hline \multicolumn{3}{|c|}{ 1982-1992 } & \multicolumn{3}{|c|}{ 1992-2002 } \\
\hline Lp. & Państwo & $\begin{array}{c}\text { Sr. roczny } \\
\% \text { wzrostu } \\
\text { w rzeczy- } \\
\text { wistym PKB }\end{array}$ & Lp. & Państwo & $\begin{array}{c}\text { Śr. roczny } \\
\text { \% wzrostu } \\
\text { w rzeczy- } \\
\text { wistym PKB }\end{array}$ \\
\hline 1. & CHINY & 10,2 & 1. & BOŚNIA I HERC. & 20,5 \\
\hline 2. & BOTSWANA & 9,8 & 2. & LIBIERIA & 9,4 \\
\hline 3 . & KOREA PŁD. & 8,7 & 3. & CHINY & 9,3 \\
\hline 4. & EKWADOR & 8,5 & 4. & MOZAMBIK & 8,4 \\
\hline 5. & TAJWAN & 8,5 & 5. & BIRMA & 8,1 \\
\hline 6. & TAJLANDIA & 8,4 & 6. & IRLANDIA & 7,7 \\
\hline 7. & MAKAU & 8,1 & 7. & WIETNAM & 7,5 \\
\hline 8. & OMAN & 7,7 & 8. & BHUTAN & 7,0 \\
\hline 9. & INDONEZJA & 7,1 & 9. & UGANDA & 6,7 \\
\hline 10. & SUNGAPUR & 7,0 & 10. & ALBANIA & 6,3 \\
\hline 11. & BHUTAN & 6,7 & 11. & LAOS & 6,3 \\
\hline 12. & SUAZI & 6,6 & 12. & SINGPUR & 6,2 \\
\hline 13. & MALEZJA & 6,5 & 13. & ERYTREA & 6,1 \\
\hline 14. & CHILE & 6,4 & 14. & ETIOPIA & 6,0 \\
\hline 15. & CYPR & 6,4 & 15 . & SUDAN & 6,0 \\
\hline 16. & HONGKONG & 6,4 & 16. & INDIE & 5,9 \\
\hline 17. & CZAD & 6,2 & 17. & DOMINIKANA & 5,7 \\
\hline 18. & PAKISTAN & 6,1 & 18. & MALEZJA & 5,7 \\
\hline 19. & MAURITIUS & 5,9 & 19. & KOREA PŁD. & 5,6 \\
\hline 20. & NOWA KALEDONIA & 5,9 & 20. & BOTSWANA & 5,3 \\
\hline 21. & LUKSEMBURG & 5,5 & 21. & MAURITIUS & 5,2 \\
\hline 22. & INDIE & 5,4 & 22. & ARMENIA & 5,0 \\
\hline
\end{tabular}

Źródło: Opracowanie własne na podstawie: The Economist, Pocket. Świat..., op. cit., s. 32-33.

- niestety większość krajów Trzeciego Świata to państwa, których organy nie zawsze działają zgodnie z zasadą praworządności, co oznacza, że praktyki korupcyjne (m.in. łapówkarstwo czy wymuszenia) sta- 
ły się podstawą funkcjonowania; powoduje to, że rozwój działalności gospodarczej odbywa się głównie w szarej strefie ${ }^{21}$.

Powyższe cechy gospodarek państw rozwijających się nie stanowią konkurencyjnej oferty dla zagranicznych inwestycji ugruntowanych i stosunkowo stabilnych gospodarek kapitalistycznych krajów rozwiniętych. Zastanawiające jest jednak to, że to właśnie powyżej opisane cechy wpływają na fakt, że kraje rozwijające się odnotowują szybki wzrost gospodarczy (tabela 3), co z kolei wpływa na obniżanie się wskaźnika bezrobocia.

\section{Podsumowanie}

Z PROBLEMEM PAŃSTW ROZWIJAJĄCYCH SIĘ związane są liczne kontrowersje. $\mathrm{Z}$ jednej strony przyznać należy, że państwa rozwinięte nie są do nich pozytywnie nastawione, ponieważ muszą liczyć się z koniecznością udzielania pomocy różnego typu, w tym finansowej oraz możliwością niewypłacalności państw rozwijających się. W związku z tym coraz głośniej wzywa się do zaprowadzenia nowego międzynarodowego porządku gospodarczego ${ }^{22}$. Z drugiej jednak strony uważa się, że państwa Trzeciego Świata są słabiej rozwinięte z przyczyn historycznych i pewnych swych cech, a zatem niezbędna jest wewnętrzna zmiana z ich strony. Vernon Van Dyke uważa, że „państwa biedne są biedne z wielu przyczyn związanych (...) prowadzoną polityką, a rozwiązanie problemów (jeśli takowe istnieje), zależy od nich samych" ${ }^{23}$. W kontekście zjawiska bezrobocia oznacza to, że przeciwdziałanie temu zjawisku jest problemem złożonym wymagającym reform na wielu płaszczyznach. Jednak proces ten już się rozpoczął, co obrazują statystyki (wzrost gospodarczy, obniżanie się wskaźnika bezrobocia). Oznacza to, że kraje rozwijające się, jak sama nazwa wskazuje, rzeczywiście się rozwijają. Daje to ogromne szanse na polepszenie jakości życia w tych państwach.

Reasumując, istotnych przyczyn trudności we wprowadzaniu skutecznej polityki rynku pracy upatrywać należy przede wszystkim w czynnikach ekonomicznych (m.in. zadłużenia państw rozwijających się i brak środków finansowych na przeprowadzanie niezbędnych reform), czynnikach politycznych (m.in. rządy reżimów wojskowych), czynnikach demograficznych (m.in. wysoki wskaźnik przyrostu demo-

\footnotetext{
${ }^{21}$ Ibidem, s. 471-472.

${ }^{22}$ V. Dyke, Wprowadzenie do polityki, Poznań 200o, s. 277.

${ }^{23}$ Ibidem, s. 277.
} 
graficznego) oraz czynnikach kulturowych. Nie można jednak znaleźć jednego rozwiązania, które niwelowałoby skutki występowania tych czynników dla wszystkich państw rozwijających się. Każde z nich musi znaleźć własną drogę rozwoju.

\section{SUMMARY}

UNEMPLOYMENT IS A PROBLEM IN PRESENT INTERNATIONAL REALITY that is common all over the world. However, developing countries are particularly exposed to the consequences of unemployment. The author explains why in developing areas, where drama of unemployment is measured not by an amount of the unemployed, but by the amount of people close to starvation, it is so difficult to combat. The article presents an attempt to analyze the situation of developing countries in the context of unemployment. What is more, a particular attention will be paid to the fact that some financial support and social and cultural changes are needed.

\section{NOTA O AUTORCE}

Patrycja Szcześniak [patrycja.szczesniak@gmail.com] - studentka II roku studiów II stopnia na kierunku stosunki międzynarodowe o specjalności współpraca europejska oraz II roku studiów II stopnia na kierunku politologia o specjalności administracja europejska na Wydziale Nauk Politycznych i Dziennikarstwa UAM w Poznaniu. Jej zainteresowania koncentrują się wokół tematyki bezpieczeństwa międzynarodowego szczególnie bezpieczeństwa socjalnego oraz polityki społecznej głównie systemów pomocy społecznej krajów Unii Europejskiej. Pracownik socjalny w Miejskim Ośrodku Pomocy Społecznej w Pile. 